\title{
ANALISIS INTERDEPENDENSI NILAI TUKAR, INFLASI, PRODUK DOMESTIK BRUTO, SUKU BUNGA DAN NERACA TRANSAKSI BERJALAN DI INDONESIA
}

\author{
Uline Afriany Prasetia Simarmata \\ Program Pascasarjana Ilmu Ekonomi Universitas Negeri Medan \\ Telp.: +628139744 2858, E-Mail : b00k 10v3rs@yahoo.com
}

\begin{abstract}
Depreciation of the rupiah prompted Bank Indonesia raised SBI to strengthen the rupiah, inflation has a downward trend when the appreciation of the rupiah, and the movement of the exchange rate also change the position of the current account of Indonesia. This study aimed to determine the role and effects of changes in exchange rates, inflation, gross domestic product, interest rates and the current account balance for each variable. Data obtained from secondary data is exchange rate, inflation, GDP, interest rates and the current account data from 2000:1 up to 2010:4. The model used in this study is the econometric model by the method of Vector Autoregressive (VAR) that in their analysis the instrument has Impulse Response Function (IRF) and Variance Decomposition (VD). The results of this study concluded that (1) All variable giving each other random shock to other variables and response by each variable so as to achieve long-term equilibrium. This is shown on the estimation IRF test on each variable; (2) All variables are mutually contribute to other variables. It is shown by the results of estimation VD test, in which each variable contributed to other variables.
\end{abstract}

Key words: Exchange Rate, Inflation, Gross Domestic Product, Interest Rate and Current Account

\section{PENDAHULUAN}

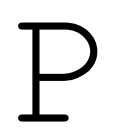

emahaman mengenai hubungan antara nilai tukar, inflasi, Pendapat Domestik Bruto (selanjutnya disingkat PDB), suku bunga dan neraca transaksi berjalan (selanjutnya disingkat NTB) merupakan hal yang penting bagi pengambil kebijakan ekonomi serta masyarakat dalam perekonomian terbuka. Pemahaman ini akan memberikan kemudahan bagi para pengambil kebijakan ekonomi maupun masyarakat dalam menanggapi adanya perubahan dari variabel ekonomi yang akan mempengaruhi nilai tukar, inflasi, PDB, suku bunga dan NTB. 
Dengan semakin terbukanya ekonomi Indonesia dengan ekonomi internasional akan berimplikasi terhadap eksisnya pengaruh variabel-variabel makro ekonomi dan ekonomi internasional terhadap kinerja makro ekonomi di atas, begitu juga akan ada saling interaksi antar variabel-variabel ekonomi. Hal ini juga berimplikasi bahwa rancangan kebijakan ekonomi yang bertujuan menstabilisasi sektor pertanian dan non pertanian serta sektor ekonomi lainnya tidak bisa lepas dari bagaimana kebijakan tersebut dilakukan secara integratif baik yang menyangkut dari sisi ekonomi pertanian, kebijakan ekonomi makro dan kebijakan perdagangan internasional.

Kekuatan makro ekonomi seperti nilai tukar, inflasi, PDB, suku bunga dan NTB memiliki keterkaitan (interdependensi) antara variabel yang satu dengan variabel yang lainnya. Kenaikan atau penurunan salah satu variabel akan berdampak terhadap kondisi variabel lainnya sebagai gambaran perekonomian di Indonesia. Sulitnya bagi pemerintah untuk menetapkan kebijakan perekonomian dikarenakan akan berdampak terhadap seluruh aspek kekuatan makro lainnya. Keterkaitan (interdependensi) antara variabel-variabel penelitian dapat dilihat dalam tabel dan grafik di bawah ini.

Tabel 1. Nilai Tukar, Inflasi, Suku Bunga, PDB dan NTB Tahun 2000-2010

\begin{tabular}{rrrrrr}
\hline Tahun & \multicolumn{1}{c}{$\begin{array}{c}\text { KURS } \\
\text { (rupiah) }\end{array}$} & \multicolumn{1}{c}{$\begin{array}{c}\text { INFA } \\
\text { (\%) }\end{array}$} & \multicolumn{1}{c}{$\begin{array}{c}\text { RATE } \\
\text { (\%) }\end{array}$} & \multicolumn{1}{c}{$\begin{array}{c}\text { PDB } \\
\text { (milyar) }\end{array}$} & $\begin{array}{c}\text { NTB } \\
\text { (milyar) }\end{array}$ \\
\hline 2000 & 9.595 & 9,4 & 14,31 & $101.197,0$ & 2.498 \\
2001 & 10.400 & 12,55 & 17,63 & $102.437,1$ & 1.140 \\
2002 & 8.940 & 10 & 13,12 & $106.104,6$ & 1.849 \\
2003 & 8.465 & 5,1 & 8,34 & $392.641,5$ & 2.391 \\
2004 & 9.290 & 6,4 & 7,4 & $418.770,8$ & 317 \\
2005 & 9.830 & 17,1 & 9,16 & $438.500,2$ & 1.253 \\
2006 & 9.020 & 6,3 & 11,96 & $465.855,9$ & 2.155 \\
2007 & 9.419 & 6,6 & 8,05 & $495.089,8$ & 3.365 \\
2008 & 10.950 & 11,1 & 9,39 & $518.935,0$ & -637 \\
2009 & 10.359 & 4,3 & 7,49 & $547.543,0$ & 3.442 \\
2010 & 9.078 & 5,3 & 6,54 & $585.102,0$ & 1.093 \\
\hline
\end{tabular}

Sumber : Bank Indonesia (diolah)

Keterkaitan antara nilai tukar dan inflasi akan semakin jelas ketika terjadi perubahan sistem nilai tukar dari sistem nilai tukar mengambang terkendali (managed floating exchange rate) ke sistem nilai tukar mengambang bebas (free floating exchange rate). Fluktuasi inflasi lebih tampak ketika periode free floating exchange rate dibandingkan periode sebelumnya. Inflasi tampak mempunyai trend menurun ketika terjadi penguatan nilai tukar rupiah jelas sekali terlihat antar tahun 2009.

Depresiasi rupiah kembali menarik perhatian sejak tahun 2005 ketika rupiah menembus level 9.830 per dolar. Kondisi ini mendorong Bank Indonesia juga menaikan SBI dari 7,4\% menjadi 9,16\% untuk memperkuat rupiah. Apresiasi nilai tukar pada tahun 2009 sampai 2010 telah membuat BI menurunkan juga suku bunga SBI dari $7,49 \%$ menjadi $6,54 \%$.

Kenyataan lain akibat depresiasi rupiah mengakibatkan barang-barang modal yang dibutuhkan industri dalam negeri mengalami lonjakan harga, yang membuat 
perusahaan mengurangi kapasitas produksi barang yang mempunyai kandungan impor tinggi. Penurunan kapasitas produksi ini menandai telah terjadi fluktuasi PDB. Dengan demikian depresiasi rupiah telah menyebabkan terjadinya penurunan PDB. Pergerakan nilai tukar rupiah ini juga ternyata merubah posisi NTB Indonesia. NTB Indonesia yang defisit pada tahun 2008 sebesar 637 miliyar rupiah berubah menjadi surplus pada tahun 2009 menjadi sebesar 3.442 miliyar rupiah. Adanya perubahan pengaruh nilai tukar terhadap perilaku inflasi, PDB, suku bunga dan NTB setelah adanya perubahan manajemen nilai tukar menunjukkan keterkaitan yang kuat antar variabel-variabel.

\section{METODOLOGI}

Interdependensi antara variabel-variabel penelitian akan dianalisis menggunakan Vector Autoregression (VAR). Data yang digunakan adalah data sekunder dalam kurun waktu 2000:1-2010:4, yang diperoleh dari Laporan Bank Indonesia. Pengolahan data dilakukan menggunakan program Eviews 4.1.

Vector Autoregression (VAR) adalah bentuk pemodelan yang digunakan untuk multivariate time series. Model VAR pertama kali dikembangkan oleh Cristoper A. Sims terutama sebagai solusi atas kritiknya terhadap model persamaan simultan (Nugraha, 2006:65).

Oleh karena itu, untuk menentukan variabel mana yang harus bersifat eksogen dan endogen dalam model VAR, pendekatan VAR berusaha membiarkan "let the data speaks for themselves" dengan membuat semua variabel bersifat endogen (Nugraha, 2006:66). Dengan demikian dalam kerangka VAR, setiap variabel baik dalam level maupun first difference, diperlakukan secara simetris di dalam sistem persamaan yang mengandung regressor set yang sama. Spesifikasi model VAR meliputi pemilihan variabel dan banyaknya selang (lag) yang digunakan dalam model. Sesuai dengan metodologi Sims, variabel yang dipergunakan didalam persamaan VAR dipilih berdasarkan model ekonomi yang relevan. Pemilihan selang optimal kemudian akan memanfaatkan kriteria informasi seperti Akaike Info Criterion (AIC), Schwartz Info Criterion (SIC) maupun Hannan-Quinn Criterion (HQ).

Dilihat dari bentuk umum model VAR adalah:

$$
\bar{Y}_{\mathrm{t}}=\sum_{i=1}^{k} A_{i} \overline{\mathrm{Y}}_{\mathrm{t}-1}+\varepsilon_{\mathrm{t}}
$$

di mana $\bar{Y}_{t}$ adalah vektor kolom pada saat $t$ untuk semua observasi, $\varepsilon_{t}$ adalah vektor kolom nilai random disturbance, yang mungkin berkorelasi pada saat sekarang satu sama lain tetapi tidak berkorelasi sepanjang waktu, $A_{i}$ adalah matrik parameter yang semuanya bernilai bukan nol. Maka semua variabel yang dilibatkan dalam penelitian ini dirumuskan dalam model VAR sebagai berikut :

$$
\begin{aligned}
\text { KURS }_{\mathrm{t}}= & \beta_{0}+\beta_{1 \mathrm{p}} \sum_{1}^{p} \mathrm{KURS}_{\mathrm{t}-\mathrm{p}}+\beta_{2 \mathrm{p}} \sum_{1}^{p} \mathrm{INFA}_{\mathrm{t}-\mathrm{p}}+\beta_{3 \mathrm{p}} \sum_{1}^{p} \mathrm{PDB}_{\mathrm{t}-\mathrm{p}}+\beta_{4 \mathrm{p}} \\
& \sum_{1}^{p} \text { RATE }_{\mathrm{t}-\mathrm{p}}+\beta_{5 \mathrm{p}} \sum_{1}^{p} \mathrm{NTB}_{\mathrm{t}-\mathrm{p}}, \varepsilon_{\mathrm{KURS}} \\
\text { INFA }_{\mathrm{t}}= & \beta_{0}+\beta_{1 \mathrm{p}} \sum_{1}^{p} \mathrm{KURS}_{\mathrm{t}-\mathrm{p}}+\beta_{2 \mathrm{p}} \sum_{1}^{p} \mathrm{INFA}_{\mathrm{t}-\mathrm{p}}+\beta_{3 \mathrm{p}} \sum_{1}^{p} \mathrm{PDB}_{\mathrm{t}-\mathrm{p}}+\beta_{4 \mathrm{p}} \\
& \sum_{1}^{p} \text { RATE }_{\mathrm{t}-\mathrm{p}}+\beta_{5 \mathrm{p}} \sum_{1}^{p} \mathrm{NTB}_{\mathrm{t}-\mathrm{p}}, \varepsilon_{\text {INFA }}
\end{aligned}
$$




$$
\begin{aligned}
\text { PDB }_{\mathrm{t}}= & \beta_{0}+\beta_{1 \mathrm{p}} \sum_{1}^{p} \mathrm{KURS}_{\mathrm{t}-\mathrm{p}}+\beta_{2 \mathrm{p}} \sum_{1}^{p} \mathrm{INFA}_{\mathrm{t}-\mathrm{p}}+\beta_{3 \mathrm{p}} \sum_{1}^{p} \mathrm{PDB}_{\mathrm{t}-\mathrm{p}}+\beta_{4 \mathrm{p}} \\
& \sum_{1}^{p} \text { RATE }_{\mathrm{t}-\mathrm{p}}+\beta_{5 \mathrm{p}} \sum_{1}^{p} \mathrm{NTB}_{\mathrm{t}-\mathrm{p}}, \varepsilon_{\mathrm{PDB}} \\
\text { RATE }_{\mathrm{t}}= & \beta_{0}+\beta_{1 \mathrm{p}} \sum_{1}^{p} \mathrm{KURS}_{\mathrm{t}-\mathrm{p}}+\beta_{2 \mathrm{p}} \sum_{1}^{p} \mathrm{INFA}_{\mathrm{t}-\mathrm{p}}+\beta_{3 \mathrm{p}} \sum_{1}^{p} \mathrm{PDB}_{\mathrm{t}-\mathrm{p}}+\beta_{4 \mathrm{p}} \\
& \sum_{1}^{p} \text { RATE }_{\mathrm{t}-\mathrm{p}}+\beta_{5 \mathrm{p}} \sum_{1}^{p} \mathrm{NTB}_{\mathrm{t}-\mathrm{p}}, \varepsilon_{\mathrm{RATE}} \\
\mathrm{NTB}_{\mathrm{t}}= & \beta_{0}+\beta_{1 \mathrm{p}} \sum_{1}^{p} \mathrm{KURS}_{\mathrm{t}-\mathrm{p}}+\beta_{2 \mathrm{p}} \sum_{1}^{p} \mathrm{INFA}_{\mathrm{t}-\mathrm{p}}+\beta_{3 \mathrm{p}} \sum_{1}^{p} \mathrm{PD}_{\mathrm{t}-\mathrm{p}}+\beta_{4 \mathrm{p}} \\
& \sum_{1}^{p} \text { RATE }_{\mathrm{t}-\mathrm{p}}+\beta_{5 \mathrm{p}} \sum_{1}^{p} \mathrm{NTB}_{\mathrm{t}-\mathrm{p}}, \varepsilon_{\mathrm{NTB}}
\end{aligned}
$$

\section{Innovation Accounting}

\section{Impulse Response Function (IRF)}

Analisis impuls respon (impuls respon function/IRF) adalah metode yang digunakan untuk menentukan respon suatu variabel endogen terhadap guncangan (shock) variabel tertentu (Amisano, 1997:78). IRF juga digunakan untuk melihat shock dari satu variabel terhadap variabel yang lain dan berapa lama (periode) pengaruh tersebut.

\section{Variance Decomposition (VD)}

Analisis Variance Decomposition (VD) digunakan untuk menghitung dan menganalisis seberapa besar pengaruh acak guncangan (random shock) dari variabel tertentu terhadap variabel endogen (Amisano, 1997:78). Singkatnya VD menghasilkan informasi mengenai relatif pentingnya masing-masing inovasi acak (random innovation structural disturbance) atau seberapa kuat komposisi dari peranan variabel tertentu terhadap variabel lainnya dalam model VAR. Alat analisis ini yang akan digunakan untuk menjawab permasalahan kedua dalam penelitian ini.

\section{Data Generating Process (DGP)}

Sebelum masuk kedalam tahapan analisis model VAR, maka sebelumnya dilakukan Data Generating Process (DGP). Ini penting dilakukan karena dalam model multivarian time-series kebanyakan data yang digunakan mengandung akar unit sehingga akan membuat hasil estimasi menjadi palsu (spurious regression) (Gujarati, 2003:70).

\section{HASIL DAN PEMBAHASAN}

\section{Analisis Impulse Response Function (IRF)}

IRF merupakan aplikasi vector moving average yang bertujuan untuk melihat seberapa lama goncangan dari satu variabel berpengaruh terhadap variabel yang lain. Respon tersebut dalam jangka pendek biasanya cukup signifikan dan cenderung berubah. Dalam jangka panjang akan cenderung konsisten dan terus mengecil. Analisis interdependensi nilai tukar, inflasi, Produk Domestik Bruto, suku bunga dan NTB di Indonesia didasarkan hasil uji IRF yang akan dilihat dalam tiga periode yaitu jangka pendek, jangka menengah dan jangka panjang. Jangka pendek adalah periode waktu dalam satu tahun ( 4 triwulan), sementara jangka menengah periode waktu selama lima tahun (20 triwulan) dan jangka panjang adalah periode diatas lima tahun (40 triwulan). Berikut hasil uji IRF dalam penelitian ini. 


\section{Impulse Response Function Nilai Tukar Rupiah}

Uji IRF ini akan menunjukkan setiap kejutan acak yang disebabkan oleh semua variabel yang akan direspon oleh variabel nilai tukar rupiah.

Tabel 6. Impulse Response Function Nilai Tukar Rupiah

\begin{tabular}{cccccc}
\hline \multirow{2}{*}{ Period } & \multicolumn{5}{c}{ Response of LOG(KURS): } \\
\cline { 2 - 5 } & LOG(KURS) & LOG(INFA) & LOG(PDB) & LOG(RATE) & LOG(NTB) \\
\hline 1 & 0.053226 & 0.000000 & 0.000000 & 0.000000 & 0.000000 \\
2 & 0.018639 & 0.012654 & -0.016379 & 0.003730 & 0.004411 \\
3 & 0.021283 & 0.008199 & -0.009839 & 0.002518 & 0.007110 \\
4 & 0.012509 & 0.005088 & -0.008787 & 0.003640 & 0.000325 \\
20 & 0.001711 & 0.000558 & -0.001534 & 0.001027 & $4.54 \mathrm{E}-05$ \\
40 & 0.000635 & 0.000211 & -0.000590 & 0.000321 & $-4.02 \mathrm{E}-06$ \\
\hline
\end{tabular}

Diolah Menggunakan Eviews

Hasil estimasi IRF nilai tukar untuk periode jangka pendek (triwulan ke-4) menyatakan bahwa setiap satu standar deviasi terjadi kejutan nilai tukar akan direspon nilai tukar itu sendiri hingga naik sebesar 0.012509 unit, sedangkan setiap satu standar deviasi terjadi kejutan inflasi akan direspon oleh nilai tukar hingga naik sebesar 0.005088 unit. Setiap satu standar deviasi terjadi kejutan Produk Domestik Bruto akan direspon nilai tukar hingga turun sebesar 0.008787 unit, demikian seterusnya terhadap variabel lainnya.

Untuk jangka menengah (triwulan ke-20) setiap satu standar deviasi terjadi kejutan nilai tukar akan direspon nilai tukar itu sendiri hingga naik sebesar 0.001711unit, sedangkan setiap satu standar deviasi terjadi kejutan inflasi akan direspon oleh nilai tukar hingga naik sebesar 0.000558 unit. Setiap satu standar deviasi terjadi kejutan Produk Domestik Bruto akan direspon nilai tukar hingga turun sebesar 0.001534 unit, demikian seterusnya terhadap variabel lainnya.

Dalam jangka panjang (triwulan ke-40) setiap satu standar deviasi terjadi kejutan nilai tukar akan direspon nilai tukar itu sendiri hingga naik sebesar 0.000635 unit, sedangkan setiap satu standar deviasi terjadi kejutan inflasi akan direspon oleh nilai tukar hingga naik sebesar 0.000211 unit. Setiap satu standar deviasi terjadi kejutan Produk Domestik Bruto akan direspon nilai tukar hingga turun sebesar 0.000590 unit, demikian seterusnya terhadap variabel lainnya.

\section{Impulse Response Function Inflasi}

Uji IRF ini akan menunjukkan setiap kejutan acak yang disebabkan oleh semua variabel yang akan direspon oleh variabel inflasi.

Hasil estimasi IRF inflasi untuk periode jangka pendek (triwulan ke-4) menyatakan bahwa setiap satu standar deviasi terjadi kejutan inflasi akan direspon inflasi itu sendiri hingga naik sebesar 0.085781 unit, sedangkan setiap satu standar deviasi terjadi 
kejutan nilai tukar akan direspon oleh inflasi hingga naik sebesar 0.022031 unit. Setiap satu standar deviasi terjadi kejutan Produk Domestik Bruto akan direspon inflasi hingga turun sebesar 0.082590 unit, demikian seterusnya terhadap variabel lainnya.

Tabel 7. Impulse Response Function Inflasi

\begin{tabular}{cccccc}
\hline & \multicolumn{5}{c}{ Response of LOG(INFA): } \\
\cline { 2 - 6 } Period & LOG(KURS) & LOG(INFA) & LOG(PDB) & LOG(RATE) & LOG(NTB) \\
\hline 1 & 0.011963 & 0.167007 & 0.000000 & 0.000000 & 0.000000 \\
2 & 0.043405 & 0.151857 & -0.038824 & 0.053168 & -0.051440 \\
3 & 0.019638 & 0.115922 & -0.082554 & 0.034161 & -0.009517 \\
4 & 0.022031 & 0.085781 & -0.082590 & 0.001900 & -0.020245 \\
20 & 0.005663 & 0.001493 & -0.005075 & 0.002010 & $-8.92 \mathrm{E}-05$ \\
40 & 0.001656 & 0.000550 & -0.001535 & 0.000842 & $-8.08 \mathrm{E}-06$ \\
\hline
\end{tabular}

Diolah menggunakan Eviews

Untuk jangka menengah (triwulan ke-20), setiap satu standar deviasi terjadi kejutan inflasi akan direspon inflasi itu sendiri hingga naik sebesar 0.001493 unit, sedangkan setiap satu standar deviasi terjadi kejutan nilai tukar akan direspon oleh inflasi hingga naik sebesar 0.005663 unit. Setiap satu standar deviasi terjadi kejutan Produk Domestik Bruto akan direspon inflasi hingga turun sebesar 0.005075 unit, demikian seterusnya terhadap variabel lainnya.

Dalam jangka panjang (triwulan ke-40), setiap satu standar deviasi terjadi kejutan inflasi akan direspon inflasi itu sendiri hingga naik sebesar 0.000550 unit, sedangkan setiap satu standar deviasi terjadi kejutan nilai tukar akan direspon oleh inflasi hingga naik sebesar 0.001656 unit. Setiap satu standar deviasi terjadi kejutan Produk Domestik Bruto akan direspon inflasi hingga turun sebesar 0.001535 unit, demikian seterusnya terhadap variabel lainnya.

\section{Impulse Response Function Produk Domestik Bruto}

Uji IRF ini akan menunjukkan setiap kejutan acak yang disebabkan oleh semua variabel yang akan direspon oleh variabel Produk Domestik Bruto sebagai berikut.

Tabel 8. Impulse Response Function Produk Domestik Bruto

\begin{tabular}{cccccc}
\hline & \multicolumn{5}{c}{ Response of LOG(PDB): } \\
\cline { 2 - 6 } Period & LOG(KURS) & LOG(INFA) & LOG(PDB) & LOG(RATE) & LOG(NTB) \\
\hline 1 & -0.066199 & -0.113593 & 0.215041 & 0.000000 & 0.000000 \\
2 & -0.100709 & -0.092844 & 0.157260 & -0.054976 & 0.012773 \\
\hline 3 & -0.118550 & -0.070361 & 0.141362 & -0.076565 & 0.039832 \\
4 & -0.118846 & -0.061595 & 0.145965 & -0.068414 & 0.015464 \\
20 & -0.060350 & -0.019897 & 0.056043 & -0.029741 & 0.000514 \\
40 & -0.020518 & -0.006812 & 0.019034 & -0.010384 & 0.000118 \\
\hline
\end{tabular}

Diolah menggunakan Eviews

Hasil estimasi IRF Produk Domestik Bruto untuk periode jangka pendek (triwulan ke-4) setiap satu standar deviasi terjadi kejutan Produk Domestik Bruto akan direspon Produk Domestik Bruto itu sendiri hingga naik sebesar 0.145965 unit, sedangkan setiap 
satu standar deviasi terjadi kejutan nilai tukar akan direspon oleh Produk Domestik Bruto hingga turun sebesar 0.118846 unit. Setiap satu standar deviasi terjadi kejutan inflasi akan direspon Produk Domestik Bruto hingga turun sebesar 0.061595 unit, demikian seterusnya terhadap variabel lainnya.

Untuk jangka menengah (triwulan ke-20), setiap satu standar deviasi terjadi kejutan Produk Domestik Bruto akan direspon Produk Domestik Bruto itu sendiri hingga naik sebesar 0.056043 unit, sedangkan setiap satu standar deviasi terjadi kejutan nilai tukar akan direspon oleh Produk Domestik Bruto hingga turun sebesar 0.060350 unit. Setiap satu standar deviasi terjadi kejutan inflasi akan direspon Produk Domestik Bruto hingga turun sebesar 0.019897 unit, , demikian seterusnya terhadap variabel lainnya.

Dalam jangka panjang (triwulan ke-40) setiap satu standar deviasi terjadi kejutan Produk Domestik Bruto akan direspon Produk Domestik Bruto itu sendiri hingga naik sebesar 0.019034 unit, sedangkan setiap satu standar deviasi terjadi kejutan nilai tukar akan direspon oleh Produk Domestik Bruto hingga turun sebesar 0.020518 unit. Setiap satu standar deviasi terjadi kejutan inflasi akan direspon Produk Domestik Bruto hingga turun sebesar 0.006812 unit, demikian seterusnya terhadap variabel lainnya.

\section{Impulse Response Function Suku Bunga}

Uji IRF ini akan menunjukkan setiap kejutan acak yang disebabkan oleh semua variabel yang akan direspon oleh variabel suku bunga sebagai berikut.

Tabel 9. Impulse Response Function Suku Bunga

\begin{tabular}{cccccc}
\hline & \multicolumn{5}{c}{ Response of LOG(RATE): } \\
\cline { 2 - 5 } Period & LOG(KURS) & LOG(INFA) & LOG(PDB) & LOG(RATE) & LOG(NTB) \\
\hline 1 & 0.014533 & 0.006761 & -0.003580 & 0.072553 & 0.000000 \\
2 & 0.040639 & 0.029196 & -0.023530 & 0.069143 & 0.006680 \\
3 & 0.048222 & 0.043330 & -0.044912 & 0.062889 & 0.001143 \\
4 & 0.053454 & 0.042639 & -0.056709 & 0.055814 & 0.001050 \\
20 & 0.032964 & 0.010990 & -0.030800 & 0.016218 & -0.000388 \\
40 & 0.011230 & 0.003728 & -0.010418 & 0.005683 & $-6.44 \mathrm{E}-05$ \\
\hline
\end{tabular}

Diolah menggunakan Eviews

Hasil estimasi IRF suku bunga untuk periode jangka pendek (triwulan ke-4) setiap satu standar deviasi terjadi kejutan suku bunga akan direspon suku bunga itu sendiri hingga naik sebesar 0.055814 unit, setiap satu standar deviasi terjadi kejutan nilai tukar akan direspon oleh suku bunga hingga naik sebesar 0.053454 unit. Setiap satu standar deviasi terjadi kejutan inflasi akan direspon suku bunga hingga naik sebesar 0.042639 unit, demikian seterusnya terhadap variabel lainnya.

Untuk jangka menengah (triwulan ke-20), setiap satu standar deviasi terjadi kejutan suku bunga akan direspon suku bunga itu sendiri hingga naik sebesar 0.016218 unit, sedangkan setiap satu standar deviasi terjadi kejutan nilai tukar akan direspon oleh suku bunga hingga naik sebesar 0.032964 unit. Setiap satu standar deviasi terjadi kejutan inflasi akan direspon suku bunga hingga naik sebesar 0.010990 unit, demikian seterusnya terhadap variabel lainnya. 
Dalam jangka panjang (triwulan ke-40), setiap satu standar deviasi terjadi kejutan suku bunga akan direspon suku bunga itu sendiri hingga naik sebesar 0.005683 unit, sedangkan setiap satu standar deviasi terjadi kejutan nilai tukar akan direspon oleh suku bunga hingga naik sebesar 0.011230 unit. Setiap satu standar deviasi terjadi kejutan inflasi akan direspon suku bunga hingga naik sebesar 0.003728 unit, demikian seterusnya terhadap variabel lainnya.

\section{Impulse Response Function NTB}

Uji IRF ini akan menunjukkan setiap kejutan acak yang disebabkan oleh semua variabel yang akan direspon oleh variabel NTB.

Tabel 10. Impulse Response Function NTB

\begin{tabular}{cccccc}
\hline & \multicolumn{5}{c}{ Response of LOG(NTB): } \\
\cline { 2 - 6 } Period & LOG(KURS) & LOG(INFA) & LOG(PDB) & LOG(RATE) & LOG(NTB) \\
\hline 1 & -0.047306 & -0.071142 & -0.010816 & 0.078319 & 0.412656 \\
2 & 0.042673 & -0.032539 & 0.131335 & 0.109696 & 0.015569 \\
3 & -0.008183 & -0.124151 & 0.098485 & 0.187897 & 0.061489 \\
4 & 0.014051 & -0.059948 & 0.063901 & 0.106844 & 0.084969 \\
20 & 0.043507 & 0.015412 & -0.041359 & 0.022730 & -0.000680 \\
40 & 0.015358 & 0.005097 & -0.014248 & 0.007762 & $-9.05 \mathrm{E}-05$ \\
\hline
\end{tabular}

Diolah menggunakan Eviews

Hasil estimasi IRF NTB untuk periode jangka pendek (triwulan ke-4), setiap satu standar deviasi terjadi kejutan NTB akan direspon NTB itu sendiri hingga naik sebesar 0.084969 unit, sedangkan setiap satu standar deviasi terjadi kejutan nilai tukar akan direspon oleh NTB hingga naik sebesar 0.014051 unit. Setiap satu standar deviasi terjadi kejutan inflasi akan direspon NTB hingga turun sebesar 0.059948 unit, demikian seterusnya terhadap variabel lainnya.

Untuk jangka menengah (triwulan ke-20), setiap satu standar deviasi terjadi kejutan NTB akan direspon NTB itu sendiri hingga turun sebesar 0.000680 unit, sedangkan setiap satu standar deviasi terjadi kejutan nilai tukar akan direspon oleh NTB hingga naik sebesar 0.043507 unit. Setiap satu standar deviasi terjadi kejutan inflasi akan direspon NTB hingga naik sebesar 0.015412 unit, demikian seterusnya terhadap variabel lainnya.

Dalam jangka panjang (triwulan ke-40), setiap satu standar deviasi terjadi kejutan NTB akan direspon NTB itu sendiri hingga turun sebesar 0.00009 unit, sedangkan setiap satu standar deviasi terjadi kejutan nilai tukar akan direspon oleh NTB hingga naik sebesar 0.015358 unit. Setiap satu standar deviasi terjadi kejutan inflasi akan direspon NTB hingga naik sebesar 0.005097 unit, demikian seterusnya terhadap variabel lainnya.

\section{Analisis Variance Decomposition (VD)}

Hasil analisis Variance Decomposition menunjukkan besaran kontribusi variabel yang satu kepada variabel yang lainnya secara simultan. Setiap variabel akan dipengaruhi oleh variabel lainnya dan total besaran komposisi kontribusi variabel tersebut adalah

$$
\text { QE Journal | Vol.01 - No.03 - } 32
$$


$100 \%$. Hal ini menunjukkan adanya hubungan yang saling mempengaruhi (kausalitas) diantara setiap variabel yang ada dan besaran komposisi dari kontribusi variabel tersebut akan merata pada jangka waktu yang lama. Hasil Variance Decomposition ini juga akan menunjukkan variabel yang mempunyai kontribusi terbesar baik dalam jangka pendek, menengah dan panjang. Hasil analisis uji Variance Decomposition adalah sebagai berikut:

\section{Variance Decomposition Nilai Tukar}

Hasil estimasi uji VD nilai tukar ditunjukkan pada Tabel 11 berikut.

Tabel 11. Variance Decomposition Nilai Tukar

\begin{tabular}{ccccccc}
\hline & \multicolumn{6}{c}{ Variance Decomposition of LOG(KURS): } \\
\cline { 2 - 7 } Period & S.E. & LOG(KURS) & LOG(INFA) & LOG(PDB) & LOG(RATE) & LOG(NTB) \\
\hline 1 & 0.053226 & 100.0000 & 0.000000 & 0.000000 & 0.000000 & 0.000000 \\
2 & 0.060350 & 87.32188 & 4.396129 & 7.365694 & 0.382072 & 0.534225 \\
3 & 0.065696 & 84.18274 & 5.267341 & 8.458554 & 0.469325 & 1.622038 \\
4 & 0.067742 & 82.58590 & 5.518097 & 9.637997 & 0.730138 & 1.527869 \\
20 & 0.070758 & 80.59184 & 5.266034 & 10.79506 & 1.613254 & 1.733808 \\
40 & 0.071160 & 80.18259 & 5.263333 & 11.10176 & 1.738048 & 1.714271 \\
\hline
\end{tabular}

Diolah menggunakan Eviews

Untuk jangka pendek pada triwulan ke-1, perkiraan error variance seluruhnya (100\%) dijelaskan oleh variabel nilai tukar rupiah itu sendiri. Ini berarti pada triwulan ke-1 nilai tukar rupiah merupakan variabel eksogen. Namun pada triwulan ke-4, seluruh variabel sudah mempunyai kontribusi terhadap perkiraan error variance, dimana nilai tukar rupiah berkontribusi paling besar terhadap nilai tukar rupiah itu sendiri sebanyak 82,59\%, Produk Domestik Bruto 9,64\%, inflasi 5,51\%, NTB 1,53\% dan suku bunga berkontribusi paling sedikit yaitu $0,73 \%$. Untuk triwulan ke-4 nilai tukar rupiah tetap menjadi variabel eksogen.

Untuk jangka menengah (triwulan ke-20), nilai tukar rupiah berkontribusi paling besar terhadap nilai tukar rupiah itu sendiri sebanyak 80,59\%, Produk Domestik Bruto 10,79\%, inflasi berkontribusi 5,26\%, NTB 1,73\% dan suku bunga berkontribusi paling sedikit yaitu $1,61 \%$. Untuk triwulan ke-20 nilai tukar rupiah tetap menjadi variabel eksogen.

Untuk jangka panjang (triwulan ke-40), nilai tukar rupiah berkontribusi paling besar terhadap nilai tukar rupiah itu sendiri sebanyak $80,18 \%$, Produk Domestik Bruto $11,10 \%$, inflasi berkontribusi $5,26 \%$, suku bunga $1,73 \%$ dan NTB berkontribusi paling sedikit yaitu $1,71 \%$. Untuk triwulan ke-40 nilai tukar rupiah tetap paling efektif berkontribusi terhadap nilai tukar itu sendiri sehingga menjadi variabel eksogen.

\section{Variance Decomposition Inflasi}

Hasil estimasi uji VD inflasi dalam tiga periode disajikan pada Tabel 12. 
Tabel 12. Variance Decomposition Inflasi

\begin{tabular}{ccccccc}
\hline & \multicolumn{6}{c}{ Variance Decomposition of LOG(INFA): } \\
\cline { 2 - 6 } Period & S.E. & LOG(KURS) & LOG(INFA) & LOG(PDB) & LOG(RATE) & \multirow{2}{*}{ LOG(NTB) } \\
\hline 1 & 0.167435 & 0.510519 & 99.48948 & 0.000000 & 0.000000 & 0.000000 \\
2 & 0.244866 & 3.380763 & 84.97759 & 2.513874 & 4.714648 & 4.413122 \\
3 & 0.286104 & 2.947529 & 78.66283 & 10.16721 & 4.879166 & 3.343265 \\
4 & 0.311342 & 2.989767 & 74.01770 & 15.62259 & 4.123924 & 3.246016 \\
20 & 0.344709 & 4.690886 & 62.69341 & 24.39803 & 4.059421 & 4.158253 \\
40 & 0.345323 & 4.841132 & 62.48626 & 24.44680 & 4.082315 & 4.143495 \\
\hline
\end{tabular}

Diolah menggunakan Eviews

Untuk jangka pendek pada triwulan ke-1, perkiraan error variance sebesar 99,48\% dijelaskan oleh variabel inflasi itu sendiri. Variabel lain yang juga dapat menjelaskan adalah nilai tukar rupiah sebesar 0,51\%. Ini berarti pada triwulan ke-1 inflasi merupakan variabel eksogen. Namun pada triwulan ke-4, seluruh variabel sudah mempunyai kontribusi terhadap perkiraan error variance, dimana inflasi berkontribusi paling besar terhadap inflasi itu sendiri sebanyak 74,01\%, Produk Domestik Bruto $15,62 \%$, suku bunga 4,12\%, NTB 3,24\% dan nilai tukar berkontribusi paling sedikit yaitu $2,98 \%$. Untuk triwulan ke-4 nilai inflasi tetap menjadi variabel eksogen.

Untuk jangka menengah (triwulan ke-20), inflasi berkontribusi paling besar terhadap inflasi itu sendiri sebanyak 62,69\%, Produk Domestik Bruto 24,39\%, nilai tukar berkontribusi 4,69\%, NTB 4,15\% dan suku bunga berkontribusi paling sedikit yaitu 4,05\%. Untuk triwulan ke-20 inflasi tetap menjadi variabel eksogen.

Untuk jangka panjang (triwulan ke-40), inflasi berkontribusi paling besar terhadap inflasi itu sendiri sebanyak 62,48\%, Produk Domestik Bruto 24,44\%, nilai tukar 4,84\%, NTB $4,14 \%$ dan suku bunga berkontribusi paling sedikit yaitu $4,08 \%$. Untuk triwulan ke40 inflasi tetap paling efektif berkontribusi terhadap inflasi itu sendiri sehingga menjadi variabel eksogen.

\section{Variance Decomposition Produk Domestik Bruto}

Hasil estimasi uji VD Produk Domestik Bruto ditampilkan pada Tabel 13.

Tabel 13. Variance Decomposition Produk Domestik Bruto

\begin{tabular}{ccccccc}
\hline & \multicolumn{6}{c}{ Variance Decomposition of LOG(PDB): } \\
\cline { 2 - 7 } Period & S.E. & LOG(KURS) & LOG(INFA) & LOG(PDB) & LOG(RATE) & LOG(NTB) \\
\hline 1 & 0.252048 & 6.898150 & 20.31116 & 72.79069 & 0.000000 & 0.000000 \\
2 & 0.331974 & 13.17947 & 19.52989 & 64.40020 & 2.742404 & 0.148039 \\
3 & 0.395782 & 18.24441 & 16.90081 & 58.06597 & 5.671790 & 1.117025 \\
4 & 0.448093 & 21.26777 & 15.07465 & 55.91115 & 6.755891 & 0.990535 \\
20 & 0.741630 & 34.12515 & 9.692222 & 47.75316 & 7.921083 & 0.508383 \\
40 & 0.782496 & 35.23378 & 9.206834 & 46.83073 & 8.271816 & 0.456833 \\
\hline
\end{tabular}

Diolah menggunakan Eviews

Dalam jangka pendek pada triwulan ke-1, perkiraan error variance sebesar $72,29 \%$ dijelaskan oleh variabel Produk Domestik Bruto itu sendiri. Variabel lain yang juga 
dapat menjelaskan adalah inflasi sebesar $20,31 \%$ dan nilai tukar rupiah sebesar $6,89 \%$. Ini berarti pada triwulan ke-1 inflasi merupakan variabel eksogen. Namun pada triwulan ke-4, seluruh variabel sudah mempunyai kontribusi terhadap perkiraan error variance, dimana Produk Domestik Bruto berkontribusi paling besar terhadap Produk Domestik Bruto itu sendiri sebanyak 55,91\%, nilai tukar 21,26\%, inflasi 15,07\%, suku bunga $6,75 \%$ dan NTB berkontribusi paling sedikit yaitu 0,99\%. Untuk triwulan ke-4 Produk Domestik Bruto tetap menjadi variabel eksogen.

Untuk jangka menengah (triwulan ke-20), Produk Domestik Bruto berkontribusi paling besar terhadap Produk Domestik Bruto itu sendiri sebanyak 47,75\%, nilai tukar 34,12\%, inflasi berkontribusi 9,69\%, suku bunga 7,92\% dan NTB berkontribusi paling sedikit yaitu $0,50 \%$.

Untuk jangka panjang (triwulan ke-40), Produk Domestik Bruto berkontribusi paling besar terhadap Produk Domestik Bruto itu sendiri sebanyak 46,83\%, nilai tukar 35,32\%, inflasi $9,20 \%$, suku bunga $8,27 \%$ dan NTB berkontribusi paling sedikit yaitu $0,45 \%$.

\section{Variance Decomposition Suku Bunga}

Hasil estimasi uji VD suku bunga ditunjukkan pada Tabel 14.

Tabel 14. Variance Decomposition Suku Bunga

\begin{tabular}{ccccccc}
\hline & \multicolumn{6}{c}{ Variance Decomposition of LOG(RATE): } \\
\cline { 2 - 7 } Period & S.E. & LOG(KURS) & LOG(INFA) & LOG(PDB) & LOG(RATE) & LOG(NTB) \\
\hline 1 & 0.074389 & 3.816997 & 0.826104 & 0.231580 & 95.12532 & 0.000000 \\
2 & 0.115830 & 13.88402 & 6.694049 & 4.222114 & 74.86727 & 0.332551 \\
3 & 0.153600 & 17.75175 & 11.76464 & 10.95050 & 59.33846 & 0.194652 \\
4 & 0.186012 & 20.36245 & 13.27643 & 16.76104 & 49.46416 & 0.135911 \\
20 & 0.358218 & 33.87107 & 9.024341 & 34.46593 & 22.53821 & 0.100453 \\
40 & 0.383425 & 35.28256 & 8.505559 & 35.01540 & 21.10850 & 0.087988 \\
\hline
\end{tabular}

Diolah menggunakan Eviews

Dalam jangka pendek triwulan ke-1, perkiraan error variance sebesar 95,12\% dijelaskan oleh variabel suku bunga itu sendiri. Variabel lain yang juga dapat menjelaskan adalah nilai tukar sebesar 3,81\%, inflasi sebesar $0,82 \%$ dan Produk Domestik Bruto sebesar 0,23\%. Ini berarti pada triwulan ke-1 suku bunga merupakan variabel eksogen. Namun pada triwulan ke-4, seluruh variabel sudah mempunyai kontribusi terhadap perkiraan error variance, dimana suku bunga berkontribusi paling besar terhadap suku bunga itu sendiri sebanyak 49,46\%, nilai tukar 20,36\%, Produk Domestik Bruto 16,76\%, inflasi 13,27\%, dan NTB berkontribusi paling sedikit yaitu $0,13 \%$.

Untuk jangka menengah (triwulan ke-20), Produk Domestik Bruto berkontribusi paling besar terhadap suku bunga sebanyak 34,46\%, nilai tukar 33,87\%, suku bunga itu sendiri berkontribusi sebesar 22,53\%, inflasi $9,02 \%$ dan NTB berkontribusi paling sedikit yaitu $0,10 \%$

Untuk jangka panjang (triwulan ke-40), nilai tukar berkontribusi paling besar terhadap suku bunga sebanyak 35,28\%, diikuti variabel Produk Domestik Bruto 35,01\%, suku 
bunga itu sendiri berkontribusi sebesar $21,10 \%$, inflasi $8,50 \%$, dan NTB berkontribusi paling sedikit yaitu $0,08 \%$.

\section{Variance Decomposition NTB}

Hasil estimasi uji VD NTB ditampilkan pada Tabel 15.

Tabel 15. Variance Decomposition NTB

\begin{tabular}{ccccccc}
\hline & \multicolumn{7}{c}{ Variance Decomposition of LOG(NTB): } \\
\cline { 2 - 7 } Period & S.E. & LOG(KURS) & LOG(INFA) & LOG(PDB) & LOG(RATE) & LOG(NTB) \\
\hline 1 & 0.428760 & 1.217315 & 2.753126 & 0.063633 & 3.336640 & 92.62929 \\
2 & 0.465015 & 1.876996 & 2.830187 & 8.030828 & 8.401375 & 78.86062 \\
3 & 0.529627 & 1.470835 & 7.676644 & 9.648712 & 19.06292 & 62.14089 \\
4 & 0.554089 & 1.408140 & 8.184318 & 10.14557 & 21.13517 & 59.12681 \\
20 & 0.656964 & 9.051814 & 7.081508 & 13.54865 & 27.34816 & 42.96987 \\
40 & 0.682935 & 11.69649 & 6.934013 & 15.45054 & 26.15466 & 39.76429 \\
\hline
\end{tabular}

Diolah menggunakan Eviews

Pada jangka pendek triwulan ke-1, perkiraan error variance sebesar 95,62\% dijelaskan oleh variabel NTB itu sendiri. Variabel lain yang juga dapat menjelaskan adalah suku bunga 3,33\%, inflasi 2,75\%, nilai tukar 1,21\% dan Produk Domestik Bruto sebesar $0,06 \%$. Ini berarti pada triwulan ke-1 semua variabel telah berkontribusi dengan NTB dan NTB merupakan variabel eksogen. Pada triwulan ke-4, seluruh variabel sudah mempunyai kontribusi terhadap perkiraan error variance, dimana NTB berkontribusi paling besar terhadap NTB itu sendiri sebanyak 59,12\%, suku bunga $21,13 \%$, Produk Domestik Bruto 10,14\%, inflasi berkontribusi $8,18 \%$, dan nilai tukar berkontribusi paling sedikit yaitu $1,40 \%$.

Untuk jangka menengah (triwulan ke-20), NTB berkontribusi paling besar terhadap NTB itu sendiri sebanyak 42,96\%, suku bunga 27,34\%, Produk Domestik Bruto 13,54\%, nilai tukar 9,05\% dan inflasi berkontribusi paling sedikit yaitu 7,08\%.

Untuk jangka panjang (triwulan ke-40), NTB berkontribusi paling besar terhadap NTB itu sendiri sebanyak 39,76\%, suku bunga 26,15\%, Produk Domestik Bruto 15,45\%, nilai tukar $11,69 \%$, dan inflasi berkontribusi paling sedikit yaitu $6,93 \%$.

\section{KESIMPULAN}

1. Hasil uji Impulse Response Function menunjukkan variabel nilai tukar, inflasi, PDB, suku bunga dan NTB terkointegrasi (mencapai keseimbangan) dalam jangka panjang;

2. Pada jangka pendek yang paling berkontribusi terhadap nilai tukar adalah nilai tukar itu sendiri, diikuti oleh PDB, inflasi, NTB dan suku bunga; pada jangka menengah yang paling berkontribusi adalah nilai tukar itu sendiri, diikuti oleh PDB, inflasi, NTB dan suku bunga; pada jangka panjang yang paling berkontribusi adalah nilai tukar itu sendiri, diikuti oleh PDB, inflasi, suku bunga dan NTB; 
3. Pada jangka pendek yang paling berkontribusi terhadap inflasi adalah inflasi itu sendiri, diikuti oleh PDB, suku bunga, NTB dan nilai tukar; pada jangka menengah yang paling berkontribusi adalah inflasi itu sendiri, diikuti oleh PDB, nilai tukar, NTB dan suku bunga; pada jangka panjang yang paling berkontribusi adalah inflasi itu sendiri, diikuti oleh PDB, nilai tukar, NTB dan suku bunga;

4. Pada jangka pendek yang paling berkontribusi terhadap PDB adalah PDB itu sendiri, diikuti oleh nilai tukar, inflasi, suku bunga dan NTB; pada jangka menengah yang paling berkontribusi adalah PDB itu sendiri, diikuti oleh nilai tukar, inflasi, suku bunga dan NTB; pada jangka panjang yang paling berkontribusi adalah PDB itu sendiri, diikuti oleh nilai tukar, inflasi, suku bunga dan NTB;

5. Pada jangka pendek yang paling berkontribusi terhadap suku bunga adalah suku bunga itu sendiri, diikuti oleh nilai tukar, PDB, inflasi dan NTB; pada jangka menengah yang paling berkontribusi adalah PDB, diikuti oleh nilai tukar, suku bunga, inflasi dan NTB; pada jangka panjang yang paling berkontribusi adalah nilai tukar, diikuti oleh PDB, suku bunga, inflasi dan NTB;

Pada jangka pendek yang paling berkontribusi terhadap NTB adalah NTB itu sendiri, diikuti oleh suku bunga, PDB, inflasi dan nilai tukar; pada jangka menengah yang paling berkontribusi adalah NTB itu sendiri, diikuti oleh suku bunga, PDB, nilai tukar dan inflasi; pada jangka panjang yang paling berkontribusi adalah NTB itu sendiri, diikuti oleh suku bunga, PDB, nilai tukar dan inflasi.

\section{DAFTAR PUSTAKA}

Amisano, Gianni dan Carlo Giannini. 1997. Topics in Structural VAR Econometrics. Springer-Verlag Berlin, Heidelberg, Germany.

Bank Indonesia. Laporan Keuangan Tahunan Bank Indonesia, 2000-2011.

Bank Indonesia. Laporan Tahunan Bank Indonesia, 2000-2011.

Enders, W. 2004. Applied Econometric Time Series, Second Edition. John Wiley \& Sony Inc.

Gujarati, Damodar. 2003. Basic Econometrics, Fourth Edition. McGraw Hill, Singapore

Haris, Richard. 1995. Cointegration Analysis in Econometric Modelling. Prentice Hall.

Nugraha, Fickry Widya. 2006. Efek Perubahan (Pass-Through Effect) Kurs Terhadap Indeks Harga Konsumen di Asean-5, Jepang dan Korea Selatan. Institut Pertanian Bogor.

Wang, Peiji. 2003. Financial Econometrics, Method and Models. Routledge Taylor \& Francis Group. 